$\begin{array}{llll}\text { Al-Rafidain Engineering } & \text { Vol.16 } & \text { No.3 } & \text { Aug. } 2008\end{array}$

\title{
Buckling Of Beams On Elastic Foundations
}

\author{
Mereen Hassan
}

Technical College - Erbil

\begin{abstract}
This study is an attempt to solve the general governing differential equation for buckling of beams resting on elastic foundation for different types of beams (pin ended, fixed ended and cantilever beams) taking into account the effect of soil sub-grade reaction value (K), axial load, lateral load and relative end settlement on the deflection and bending moment of the beams for prismatic and non-prismatic beams.

Approximate solutions are also presented using the extermization of the total potential energy equation (Rayleigh-Ritz method) using approximate shape functions for the deflection which satisfy the boundary conditions of the beam. The results show that one term series approximate solution gives acceptable results in comparison with the exact solution for practical case, the accuracy of the solution increases with increasing the number of terms up to 5 terms, beyond this limit the accuracy of the solution does not change. Buckling load increases linearly with increasing $(\mathrm{K})$ while the deflection and the bending moment exponentially decrease with increasing $(\mathrm{K})$.
\end{abstract}

Keywords: Bending moment, Buckling, Cantilever beam, Deflection, Fixed ended beam, Non-prismatic beam, Pin ended beam, Prismatic beam, Settlement and Soil sub-grade reaction.

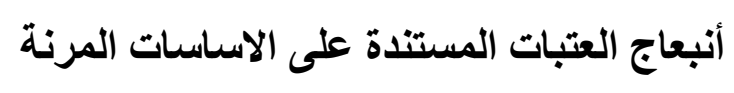

ميرين حسن 


\begin{tabular}{llll} 
Al-Rafidain Engineering & Vol.16 & No.3 & Aug. \\
\hline
\end{tabular}

$$
\text { الكلية التقنية - أربيل }
$$

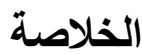

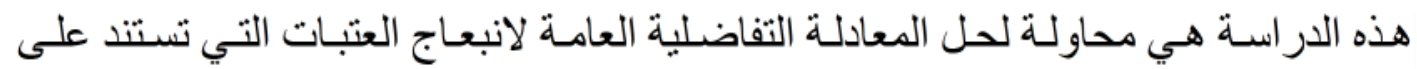

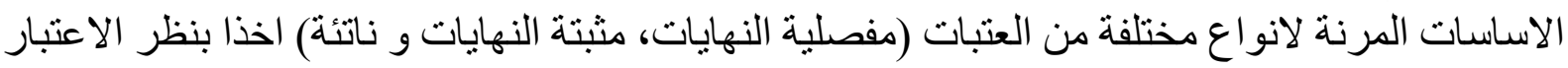

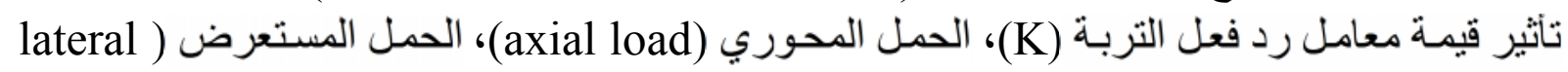

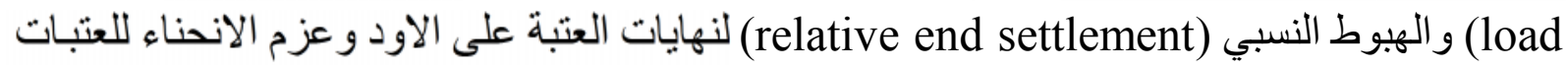

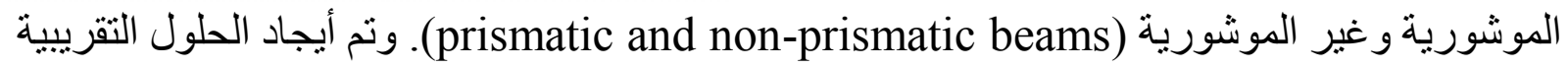

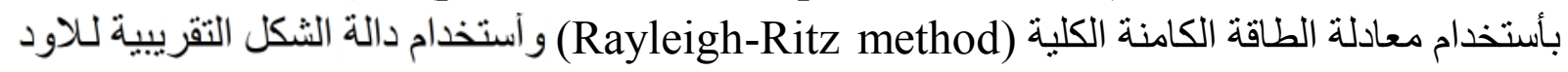

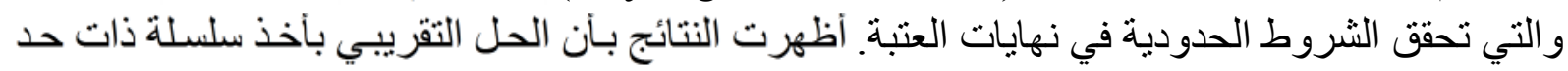

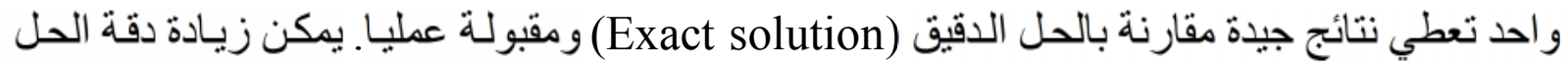

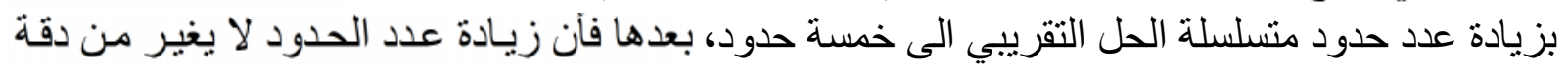

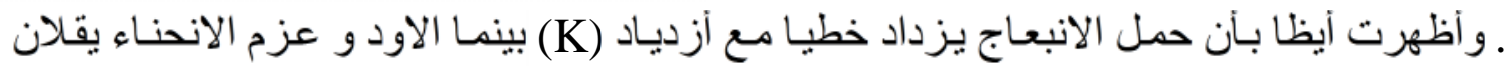

(K) مع أزدياد (exponentially)

Received 4 Dec. 2005

Accepted 9 Sep. 2007

\section{Notations:}

E : Modulus of elasticity.

$f(x)$ : Function of changing the moment of inertia.

$\mathrm{F}:$ Tapered beam factor $=\mathrm{F}(\zeta)$

$\mathrm{h}_{1}$ : Smallest depth of the beam.

$\mathrm{h}_{2}$ : Largest depth of the beam. 
I : Moment of inertia of the beam cross section.

$\mathrm{K}$ : Soil sub-grade reaction.

$\mathrm{L}$ : Span length of the beam.

$\mathrm{M}$ : Bending moment.

P : Axial load.

Pcr : Euler buckling load.

Po : Euler buckling load when $(\mathrm{K}=0)$.

$\mathrm{Q}(\mathrm{x})$ : Lateral load.

Qo : Intensity of the lateral load.

w : Deflection of the beam.

$\Delta:$ Relative end settlement of the beam.

$\Pi$ : Total potential energy of the beam.

$\alpha: \mathrm{P} / \mathrm{EI}$

$\beta: \mathrm{K} / \mathrm{EI}$

$\zeta: \mathrm{h}_{2} / \mathrm{h}_{1}-1$

\section{Introduction:}

The critical buckling load for the beam under axial compression can be determined by considering the simultaneous action of compressive and bending moment by assuming an initial curvature or by considering the behavior of an ideal column, which is assumed initially to be perfectly straight, compressed by centrically applied load, the column to be perfectly elastic and the stress within the proportional limit. If the axial load $(\mathrm{P} \leq \mathrm{Pcr})$; the bar remain straight and the column is in elastic stability condition, which means that if lateral force is applied, a small deflection is produced. The deflection disappears when the lateral load is removed and the bar retains its original form. If the axial load (P > Pcr); the bar becomes unstable and a small lateral force will produce a deflection 
which does not disappear when the lateral load is removed [1-3]. In beam on elastic foundation, the elastic media can be represented by an equally spaced elastic supports of equal rigidity. The reaction of the medium at any cross section of the bar is then proportional to the deflection at that section. The stability can be increased by using non-prismatic bars, these type of sections are very often used in steel structures. The solution of the differential equation of the gradually changing cross section including a truncated cone and pyramid is presented in ref. [1].

The main objectives of this study are to:

1- Extend the buckling problem of the beams on elastic foundation to include three types of beams (pin ended, fixed ended and cantilever) using exact solution of the governing differential equation and approximate method using (Rayleigh-Ritz) energy method.

2- Extend the analysis to include non-prismatic beams whose depths are varying linearly or parabolically.

3- Extend the analysis to include the effect of the relative end settlement on the deflection and the bending moment of the beam using both exact solution and approximate solution.

\section{Theory And Analysis:}

The total governing differential functional for the beam resting on elastic foundation subjected to axial compression force (P) and uniform lateral distributed load $\mathrm{Q}(\mathrm{x})$ can be written as [1-3]:

$\Pi=\int\left[E I / 2\left(w^{\prime \prime}\right)^{2}+K / 2(w)^{2}-P / 2\left(w^{\prime}\right)^{2}-Q(x) w\right] d x$ $--(1)$

And the governing differential equation of the problem (Euler-Lagrange equation) for this functional can be written as below:

$\mathrm{EI} \mathrm{w}^{\mathrm{IV}}+\mathrm{P}_{\mathrm{w}}{ }^{\mathrm{II}}+\mathrm{Kw}=\mathrm{Q}(\mathrm{x})$

\section{I- Elementary buckling of prismatic beams $[1,2,4-8]$ :}


The governing differential equation for beams subjected to axial compressive force $(\mathrm{P})$ and uniform lateral distributed load $\mathrm{Q}(\mathrm{x})$ for $(\mathrm{K}=0)$ becomes as:

$\mathrm{EI} \mathrm{w}^{\mathrm{IV}}+\mathrm{P} \mathrm{w}^{\mathrm{II}}=\mathrm{Q}(\mathrm{x})$

The principle of superposition is not possible in equation (3) between the two conditions:

1- $\mathrm{Q}(\mathrm{x})=0 ; \mathrm{EI} \mathrm{w}^{\mathrm{IV}}+\mathrm{P}^{\mathrm{II}}=0$

2- $\mathrm{P}=0 ; \mathrm{EI} \mathrm{w}^{\mathrm{IV}}=\mathrm{Q}(\mathrm{x})$

Because the effect of axial force on the deflection (w) will directly depends on the deflection that $\mathrm{Q}(\mathrm{x})$ induces, this means there is a non-linearity action in the behavior when $(\mathrm{P})$ and $\mathrm{Q}(\mathrm{x})$ act together.

The exact solution of equation (4) is given by:

$\mathrm{w}=\mathrm{A} \sin \left(\mathrm{k}_{1} \mathrm{x}\right)+\mathrm{B} \cos \left(\mathrm{k}_{1} \mathrm{x}\right)+\mathrm{C} \mathrm{x}+\mathrm{D}$

where: $\mathrm{k}_{1}^{2}=\mathrm{P} / \mathrm{EI}$

The constants A, B, C and D are determined for different types of beams by applying the boundary conditions at the ends.

1- Pin ended beam: the deflection $(\mathrm{w}=0)$ and the bending moment $(\mathrm{w}=0)$ at $(x=0)$ and $(x=L)$, apply these conditions to equation (6) and solve for the constants to obtain:

$\mathrm{B}=\mathrm{C}=\mathrm{D}=0$ and $\mathrm{k}_{1}=\mathrm{n} \pi / \mathrm{L}$

The deflection equation $w=A \sin (n \pi x / L)$ and the buckling load Pcr $=n^{2} \pi^{2} E I / L^{2}$

2- Fixed ended beam: the deflection $(\mathrm{w}=0)$ and the slope $\left(\mathrm{w}^{\prime}=0\right)$ at $(\mathrm{x}=0)$ and $(\mathrm{x}=\mathrm{L})$, the constants obtained from these equations:

$\mathrm{B}+\mathrm{D}=0$

-(7-a) 
$\mathrm{A} \mathrm{k}_{1}+\mathrm{C}=0$

$-(7-b)$

$A \sin \left(\mathrm{k}_{1} \mathrm{~L}\right)+\mathrm{B} \cos \left(\mathrm{k}_{1} \mathrm{~L}\right)+\mathrm{C} \mathrm{L}+\mathrm{D}=0$

$-(7-c)$

$A k_{1} \cos \left(k_{1} L\right)-B k_{1} \sin \left(k_{1} L\right)+C=0$

$-(7-d)$

The characteristic equation is:

$\sin \left(\mathrm{k}_{1} \mathrm{~L} / 2\right)\left[\mathrm{k}_{1} \mathrm{~L} / 2 \cos \left(\mathrm{k}_{1} \mathrm{~L} / 2\right)-\sin \left(\mathrm{k}_{1} \mathrm{~L} / 2\right)\right]=0$

one solution of this equation is $\sin \left(\mathrm{k}_{1} \mathrm{~L} / 2\right)=0$ and then $\left(\mathrm{k}_{1}=2 \mathrm{n} \pi / \mathrm{L}\right)$

The deflection equation $\mathrm{w}=\mathrm{B}[\cos (2 \mathrm{n} \pi \mathrm{x} / \mathrm{L})-1]$ and the buckling load Pcr $=4 \mathrm{n}^{2} \pi^{2}$ $\mathrm{EI} / \mathrm{L}^{2}$

3- Cantilever beam: the deflection $(\mathrm{w}=0)$ and the slope $\left(\mathrm{w}^{\prime}=0\right)$ at $(\mathrm{x}=0)$ and the bending moment $\left(w^{\prime \prime}=0\right)$ and the shear force $\left(w^{\prime \prime}+\mathrm{k}_{1}^{2} \mathrm{w}^{\prime}=0\right)$ at $(\mathrm{x}=\mathrm{L})$.

The deflection equation $\mathrm{w}=\mathrm{B}[1-\cos ((2 \mathrm{n}-1) \pi \mathrm{x} / 2 \mathrm{~L})]$ and $\mathrm{k}_{1}=(2 \mathrm{n}-1) \pi / 2 \mathrm{~L}$ and the buckling load Pcr $=(2 n-1)^{2} \pi^{2} E I / 4 L^{2}$

4- Fixed - Hinged beam: the deflection $(\mathrm{w}=0)$ and the slope $\left(\mathrm{w}^{\prime}=0\right)$ at $(\mathrm{x}=0)$ and the deflection $(\mathrm{w}=0)$ and the bending moment $(\mathrm{w}=0)$ at $(\mathrm{x}=\mathrm{L})$

The constants obtained from these equations:

$\mathrm{B}+\mathrm{D}=0$

$\mathrm{A} \mathrm{k} \mathrm{k}_{1}+\mathrm{C}=0$

$\mathrm{C} \mathrm{L}+\mathrm{D}=0$

$(9-c)$

$\mathrm{A} \sin \left(\mathrm{k}_{1} \mathrm{~L}\right)+\mathrm{B} \cos \left(\mathrm{k}_{1} \mathrm{~L}\right)=0$

$-(9-d)$ 


\begin{tabular}{llll} 
Al-Rafidain Engineering & Vol.16 & No.3 & Aug. 2008 \\
\hline
\end{tabular}

The characteristic equation is: $\tan \left(\mathrm{k}_{1} \mathrm{~L}\right)=\mathrm{k}_{1} \mathrm{~L}$ $--(10)$

The smallest solution is $\mathrm{k}_{1} \mathrm{~L}=4.493$ and the buckling load is $\mathrm{Pcr}=2 \pi^{2} \mathrm{EI} / \mathrm{L}^{2}$

The buckling load can also be determined using stationary total potential energy method [3] as below:

$\left.\mathrm{Pcr}=\int \mathrm{EI}(\mathrm{w})^{2}\right)^{2} \mathrm{dx} / \int\left(\mathrm{w}^{\prime}\right)^{2} \mathrm{dx}$

using the stress resultant displacement relation $(\mathrm{M}=-\mathrm{EI} \mathrm{w}$ ”), equation (11) becomes:

$\operatorname{Pcr}=\int \mathrm{M}^{2} / \mathrm{EI} \mathrm{dx} / \int\left(\mathrm{w}^{\prime}\right)^{2} \mathrm{dx}$

\section{II- Buckling of beams on elastic foundation [1-3]:}

\section{1- Pin ended beam:}

The general expression for the deflection curve of a bar with hinged ends can be represented by series of sine waves as shown in previous section:

$\mathrm{w}=\Sigma \mathrm{An} \sin \mathrm{n} \pi \mathrm{x} / \mathrm{L}$

Substitute in equation (1) and extremize the functional with respect to (An), the critical buckling load is:

$\mathrm{Pcr}=\pi^{2} \mathrm{EI} / \mathrm{L}^{2}\left[\mathrm{n}^{2}+\mathrm{KL}{ }^{4} /\left(\mathrm{n}^{2} \pi^{4} \mathrm{EI}\right)\right]$

or

$\left.\mathrm{Pcr} / \mathrm{Po}=1+\mathrm{KL}^{4} /\left(\mathrm{n}^{4} \pi^{4} \mathrm{EI}\right)\right]$ $--(15)$

where $\mathrm{n}$ is an integer and Po is the Euler buckling load of the beam when $(\mathrm{K}=0)$. 
Equation (14) gives the critical load (Pcr) as a function of (n), which represents the number of half sine waves in which the bar is subdivided at buckling. When $(\mathrm{K}=0)$, the resulting critical load $\left(\mathrm{Pcr}=\mathrm{n}^{2} \pi^{2} \mathrm{EI} / \mathrm{L}^{2}\right)$ is the exact form of Euler load.

If $(\mathrm{K})$ is very small and greater than zero, (n) should be taken as unity, thus for very flexible elastic foundation, the bar buckles without an intermediate inflection point. By gradually increasing $(\mathrm{K})$, one finally conclude that at a condition $(n=2)$ the critical load is smaller than at $(n=1)$, but equation (14) should give the same result at $(n=1)$ and $(n=2)$ to give the limiting value of $(K)$ that satisfies the condition of buckling with an intermediate inflection point.

$1+\mathrm{KL}^{4} /\left(\pi^{4} \mathrm{EI}\right)=4+\mathrm{KL}^{4} /\left(4 \pi^{4} \mathrm{EI}\right)$

$--(16)$

From which $\mathrm{KL}^{4} /\left(\pi^{4} \mathrm{EI}\right)=4$ and $\mathrm{Ko}=4 \pi^{4} \mathrm{EI} / \mathrm{L}^{4}$

when $\mathrm{K} \unlhd \mathrm{Ko}$; the deflection curve of the buckled bar has no inflection point and $(\mathrm{n}=1)$.

when $\mathrm{K}>\mathrm{Ko}$; the deflection curve of the buckled bar has an inflection point and $(n=2)$ and the span is subdivided into two half sine waves.

To generalize equation (16), the equation is to be written in the following form:

$\mathrm{n}^{2}+\mathrm{KL}^{4} /\left(\mathrm{n}^{2} \pi^{4} \mathrm{EI}\right)=(\mathrm{n}+1)^{2}+\mathrm{KL}^{4} /\left((\mathrm{n}+1)^{2} \pi^{4} \mathrm{EI}\right)$

From which $\mathrm{KL}^{4} /\left(\pi^{4} \mathrm{EI}\right)=\mathrm{n}^{2}(\mathrm{n}+1)^{2}$ and $\mathrm{Kon}=\mathrm{n}^{2}(\mathrm{n}+1)^{2} \pi^{4} \mathrm{EI} / \mathrm{L}^{4}$

Neglecting (1) as compared to (n), then:

$\mathrm{KL}^{4} /\left(\pi^{4} \mathrm{EI}\right)=\mathrm{n}^{4}$ or $(\mathrm{L} / \mathrm{n})^{4}=\pi^{4} \mathrm{EI} / \mathrm{K}$ and $\mathrm{Kon}=\mathrm{n}^{4} \pi^{4} \mathrm{EI} / \mathrm{L}^{4}$

Substituting in equation (14), to obtain:

Pcr $=2 n^{2} \pi^{2} E I / L^{2}$ or Pcr $=2 \sqrt{ } \mathrm{EI} \mathrm{K}$

The critical load (Pcr) of the beam on elastic foundation is twice the critical load for beam when $(\mathrm{K}=0)$ for the same properties.

The governing differential equation (2) can be written in the following form: 
$\mathrm{w}^{\mathrm{IV}}+\alpha \mathrm{w}^{\mathrm{II}}+\beta \mathrm{w}=\mathrm{Q}(\mathrm{x}) / \mathrm{EI}$

$--(18)$

where: $\alpha=\mathrm{P} / \mathrm{EI}$ and $\beta=\mathrm{K} / \mathrm{EI}$

For the case $(\mathrm{K}>0)$ and $\sqrt{ }(\alpha / 2)^{2}-\beta<(\alpha / 2)$, the general solution of equation (18) is:

$\mathrm{w}=\mathrm{A}_{1} \cos \left(\lambda_{1} \mathrm{x}\right)+\mathrm{A}_{2} \sin \left(\lambda_{1} \mathrm{x}\right)+\mathrm{A}_{3} \cos \left(\lambda_{2} \mathrm{x}\right)+\mathrm{A}_{4} \sin \left(\lambda_{2} \mathrm{x}\right)+\mathrm{Qo} / \mathrm{K}$

where:

$\lambda_{1}=\sqrt{ }(\alpha / 2)-\sqrt{ }(\alpha / 2)^{2}-\beta$ and $\lambda_{2}=\sqrt{ }(\alpha / 2)+\sqrt{ }(\alpha / 2)^{2}-\beta$

Imposing the boundary condition of pin ended beam, $A_{1}=A_{3}=0$ and $\lambda_{1}=\lambda_{2}=n \pi / L$ and the deflection equation $\mathrm{w}=\left(\mathrm{A}_{2}+\mathrm{A}_{4}\right) \sin (\mathrm{n} \pi \mathrm{x} / \mathrm{L})$ or $\mathrm{w}=\mathrm{A} \sin (\mathrm{n} \pi \mathrm{x} / \mathrm{L})$, this is the same shape function which is used in energy method and derived in previous section. The critical load equation is:

$\mathrm{Pcr} / \mathrm{Po}=1+\mathrm{KL}^{4} /\left(\mathrm{n}^{4} \pi^{4} \mathrm{EI}\right)$

where Po is the Euler load of the pin ended beam when $(K=0)=n^{2} \pi^{2} E I / L^{2}$

This equation is exactly similar to that obtained by energy (Rayleigh-Ritz) method.

For the case $(\alpha / 2)^{2}=\beta$ or Pcr $=2 \sqrt{ } \mathrm{EI} K$, the general solution is:

$w=A_{1} \cos (\lambda x)+A_{2} \sin (\lambda x)+A_{3} x \cos (\lambda x)+A_{4} x \sin (\lambda x)+Q o / K$

where: $\lambda^{2}=\mathrm{P} /(2 \mathrm{EI})$

Imposing the boundary condition of hinged beam, and solve for the constants, one obtain:

$\mathrm{A}_{1}=-\mathrm{Qo} / \mathrm{K}$

(22-a)

$\mathrm{A}_{4}=-$ Qo $\lambda /(2 \mathrm{~K})$ 
$\mathrm{A}_{3}=\mathrm{Qo} \lambda /(2 \mathrm{~K})[\cos (\lambda \mathrm{L})-1] /[\lambda \mathrm{L} \cos (\lambda \mathrm{L})-\sin (\lambda \mathrm{L})]$

$(22-c)$

$\mathrm{A}_{2} \sin (\lambda \mathrm{L})=\mathrm{Qo} / \mathrm{K}[\cos \lambda \mathrm{L}+\lambda \mathrm{L} / 2 \sin \lambda \mathrm{L}-1-\lambda \mathrm{L} / 2 \cos \lambda \mathrm{L}(\cos \lambda \mathrm{L}-1) /(\lambda \mathrm{L} \cos \lambda \mathrm{L}-\sin \lambda \mathrm{L})]-$ $(22-d)$

For $(\mathrm{Qo}=0), \mathrm{A}_{1}=\mathrm{A}_{3}=\mathrm{A}_{4}=0$ and $\mathrm{A}_{2} \sin (\lambda \mathrm{L})=0$, then $\lambda=\mathrm{n} \pi / \mathrm{L}$

Also the same deflection equation is obtained $\mathrm{w}=\mathrm{A}_{2} \sin (\mathrm{n} \pi / \mathrm{L})$ and the buckling load $\mathrm{Pcr}=2 \mathrm{n}^{2} \pi^{2} \mathrm{EI} / \mathrm{L}^{2}$ and $\mathrm{K}=\mathrm{n}^{4} \pi^{4} \mathrm{EI} / \mathrm{L}^{4}$, these equations are similar to those obtained by the energy method.

2- Fixed ended beam: the deflection $(\mathrm{w}=0)$ and the slope $\left(\mathrm{w}^{\prime}=0\right)$ at $(\mathrm{x}=0)$ and $(x=L)$, apply these boundary conditions into equation (21) for case $(\alpha / 2)^{2}=\beta$ and solve for the constants:

$\mathrm{A}_{1}=-\mathrm{Qo} / \mathrm{K}$

(23-a)

$\mathrm{A}_{2}=\mathrm{Qo} / \mathrm{K}[\lambda \mathrm{L}+\cos (\lambda \mathrm{L}) \sin (\lambda \mathrm{L})] /\left[\sin (\lambda \mathrm{L})^{2}-(\lambda \mathrm{L})^{2}\right]$

(23-b)

$\mathrm{A}_{3}=-\mathrm{Qo} \lambda / \mathrm{K}[\lambda \mathrm{L}+\cos (\lambda \mathrm{L}) \sin (\lambda \mathrm{L})] /\left[\sin (\lambda \mathrm{L})^{2}-(\lambda \mathrm{L})^{2}\right]$

$(23-c)$

$\mathrm{A}_{4}=-\mathrm{Qo} \lambda / \mathrm{K}\left[\sin (\lambda \mathrm{L})^{2}\right] /\left[\sin (\lambda \mathrm{L})^{2}-(\lambda \mathrm{L})^{2}\right]$

(23-d)

The characteristic or transcendental equation is:

$12 Z^{2} \sin Z+Z \sin Z \sin 4 Z-(2 \sin Z+Z \cos Z)(1-\cos 4 Z)=0$

where: $\mathrm{Z}=\lambda \mathrm{L} / 2$

One solution of the above equation is $(Z=n \pi)$, then $\lambda=2 n \pi / L=\sqrt{P} / 2 E I$

The critical load in this case $\mathrm{Pcr}=8 \mathrm{n}^{2} \pi^{2} \mathrm{EI} / \mathrm{L}^{2}$

But Po $=4 n^{2} \pi^{2} E I / L^{2}$, thus Pcr $=2$ Po 
This is the same as that concluded in a pin ended beam, the critical load (Pcr) of the beam on elastic foundation is twice the critical load for beam when $(K=0)$ for the same properties and for the case $(\alpha / 2)^{2}=\beta$.

The general expression for the deflection curve of a bar with fixed ends can be written as a series of cosine terms as shown in the previous section:

$\mathrm{w}=\sum \operatorname{An}[1-\cos (2 \mathrm{n} \pi \mathrm{x} / \mathrm{L})]$

Substitute in equation (1) and extremis the functional with respect to (An) to obtain:

$\mathrm{Pcr}=4 \pi^{2} \mathrm{EI} / \mathrm{L}^{2}\left[\mathrm{n}^{2}+3 \mathrm{KL}^{4} /\left(16 \mathrm{n}^{2} \pi^{4} \mathrm{EI}\right)\right]$

or

$\left.\mathrm{Pcr} / \mathrm{Po}=1+3 \mathrm{KL}^{4} /\left(16 \mathrm{n}^{4} \pi^{4} \mathrm{EI}\right)\right]$

when $(\mathrm{K})$ is very small and greater than zero, (n) should be taken as unity, thus for very flexible elastic foundation, the bar buckle without an intermediate inflection point. By gradually increasing of $(\mathrm{K})$, we finally arrive that at a condition for $(n=2)$ the critical load is smaller than at $(n=1)$, but equation (26) should gives the same result at $(n=1)$ and $(n=2)$. The limiting value of $(K)$ that satisfy the condition of buckling with an intermediate inflection point.

$1+3 \mathrm{KL}^{4} /\left(16 \pi^{4} \mathrm{EI}\right)=4+1 / 43 \mathrm{KL}^{4} /\left(16 \pi^{4} \mathrm{EI}\right)$

From which $3 \mathrm{KL}^{4} /\left(16 \pi^{4} \mathrm{EI}\right)=4$ and $\mathrm{Ko}=64 / 3 \pi^{4} \mathrm{EI} / \mathrm{L}^{4}$

when $\mathrm{K} \ \mathrm{Ko}, \mathrm{n}=1$; the deflection curve of the buckled bar has no inflection point.

when $\mathrm{K}>\mathrm{Ko}, \mathrm{n}=2$; the deflection curve of the buckled bar has an inflection point.and the span subdivided into two half sine waves.

To generalize equation (28), the equation is to be written in the following form: 
$\mathrm{n}^{2}+1 / \mathrm{n}^{2} 3 \mathrm{KL}^{4} /\left(16 \pi^{4} \mathrm{EI}\right)=(\mathrm{n}+1)^{2}+1 /(\mathrm{n}+1)^{2} 3 \mathrm{KL}^{4} /\left(16 \pi^{4} \mathrm{EI}\right)$ $-(29)$

From which $3 \mathrm{KL}^{4} /\left(16 \pi^{4} \mathrm{EI}\right)=\mathrm{n}^{2}(\mathrm{n}+1)^{2}$ and $\mathrm{Kon}=\mathrm{n}^{2}(\mathrm{n}+1)^{2} 16 \pi^{4} \mathrm{EI} /\left(3 \mathrm{~L}^{4}\right)$

Neglecting (1) as compared to (n), then:

$3 \mathrm{KL}^{4} /\left(16 \pi^{4} \mathrm{EI}\right)=\mathrm{n}^{4}$ or $(\mathrm{L} / \mathrm{n})^{4}=16 \pi^{4} \mathrm{EI} /(3 \mathrm{~K})$ and $\mathrm{Kon}=16 \mathrm{n}^{4} \pi^{4} \mathrm{EI} /\left(3 \mathrm{~L}^{4}\right)$

Substituting in equation (26), to obtain:

$\mathrm{Pcr}=8 \mathrm{n}^{2} \pi^{2} \mathrm{EI} / \mathrm{L}^{2}$ or Pcr $=\sqrt{ } 3(2 \sqrt{ } \mathrm{EI} \mathrm{K})$

This is exactly similar to the exact solution. Also (Pcr) for fixed ended beam is greater than pin ended beam by $(\sqrt{3})$ with the same properties and for case $(\alpha / 2)^{2}$ $=\beta$.

3- Cantilever beam: the general approximate expression for the deflection curve that satisfies the boundary conditions is:

$\mathrm{w}=\sum \operatorname{An}[1-\cos (\mathrm{n} \pi \mathrm{x} / 2 \mathrm{~L})]$

And following the same previous procedures, the critical buckling load is:

$\operatorname{Pcr} / \operatorname{Po}=1+16[3 n \pi-8 \sin (n \pi / 2)] /(\mathrm{n} \pi) \mathrm{KL}^{4} /\left(\mathrm{n}^{4} \pi^{4} \mathrm{EI}\right)$

For $\mathrm{n}=1, \mathrm{Pcr} / \mathrm{Po}=1+[16(3 \pi-8) / \pi] \mathrm{KL}^{4} /\left(\pi^{4} \mathrm{EI}\right)$

The limiting value of $(\mathrm{K})$ that satisfy the condition of buckling with an intermediate inflection point is $\mathrm{Ko}=0.55 \pi^{4} \mathrm{EI} / \mathrm{L}^{4}$

Taking (n) terms series and following the same previous steps:

$16[3 n \pi-8 \sin (n \pi / 2)] /(n \pi) \quad K^{4} /\left(\pi^{4} E I\right)=n^{4}$

Substituting in equation (31), to obtaine:

Pcr $=\sqrt{ }[3 n \pi-8 \sin (n \pi / 2)] /(n \pi)(2 \sqrt{ } E I K)$ 
and $\operatorname{Kon}=n^{5} \pi^{5} \mathrm{EI} /\left[16\{3 n \pi-8 \sin (n \pi / 2)\} \mathrm{L}^{4}\right]$

For $\mathrm{n}=1 ; \operatorname{Pcr}=2 / 3(2 \sqrt{ } \mathrm{EI} K)$

This means that (Pcr) for a cantilever beam is $(2 / 3)$ of the pin ended beam with the same properties and for the case $(\alpha / 2)^{2}=\beta$.

Table (1) shows (Ko) and (Pcr) of the beams with respect to values of pin ended beam.

Table (1): Comparison of (Ko and Pcr) for different beams

\begin{tabular}{|l|c|c|}
\hline Beam type & $\begin{array}{c}\text { Fixed ended } \\
\text { beam }\end{array}$ & Cantilever beam \\
\hline $\mathrm{Ko} / \mathrm{Ko}_{\text {(pin ended) }}$ & $16 / 3$ & 0.14 \\
\hline $\mathrm{Pcr} / \mathrm{Pcr}_{\text {(pin ended) }}$ & $\sqrt{3}$ & $2 / 3$ \\
\hline
\end{tabular}

Equations (20, 27 and 31) can be written in one general form as:

$\mathrm{Pcr} / \mathrm{Po}=1+\mathrm{a} \mathrm{KL}^{4} /\left(\pi^{4} \mathrm{EI}\right)$

or

$\operatorname{PcrL}^{2} /\left(\pi^{2} \mathrm{EI}\right)=\mathrm{a}_{1}+\mathrm{a}_{2} \mathrm{KL}^{4} /\left(\pi^{4} \mathrm{EI}\right)$

where $\left(\mathrm{a}, \mathrm{a}_{1}\right.$ and $\left.\mathrm{a}_{2}\right)$ are constants shown in Table (2)

Table (2): Value of the constants (a, $a_{1}$ and $\left.a_{2}\right)$

\begin{tabular}{|l|c|c|c|}
\hline Beam type & $\mathrm{a}$ & $\mathrm{a}_{1}$ & $\mathrm{a}_{2}$ \\
\hline Pin ended & 1 & 1 & 1 \\
\hline Fixed ended & $3 / 16$ & 4 & $3 / 4$ \\
\hline Cantilever & $16(3 \pi-8) / \pi$ & $1 / 4$ & $4(3 \pi-$ \\
& & & $8) / \pi$ \\
\hline
\end{tabular}


Figs.(1 and 2) show the plot of equations (36 and 37), as shown the value of buckling load of beams resting on elastic foundation increased linearly with increasing of the soil sub-grade reaction value.

\section{III- Settlement of beams on elastic foundation:}

The governing differential equation of the problem (Euler-Lagrange equation) for beams resting on elastic foundation subjected to lateral distributed load can be written as:

$\mathrm{EI} \mathrm{w}^{\mathrm{IV}}+\mathrm{K} \mathrm{w}=\mathrm{Q}(\mathrm{x})$ $--(38)$

The general exact solution is:

$\mathrm{w}=\left(\mathrm{k}_{1} \cosh \lambda \mathrm{x}+\mathrm{k}_{2} \sinh \lambda \mathrm{x}\right) \cos \lambda \mathrm{x}+\left(\mathrm{k}_{3} \cosh \lambda \mathrm{x}+\mathrm{k}_{4} \sinh \lambda \mathrm{x}\right) \sin \lambda \mathrm{x}+\mathrm{Qo} / \mathrm{K}$ - (39)

where $\lambda^{4}=\mathrm{K} /(4 \mathrm{EI})$

and using the stress resultant displacement relation $(\mathrm{M}=-\mathrm{EI} w$ "), the bending moment equation is:

$\mathrm{M}=-2 \mathrm{EI} \lambda^{2}\left[-\left(\mathrm{k}_{1} \sinh \lambda \mathrm{x}+\mathrm{k}_{2} \cosh \lambda \mathrm{x}\right) \sin \lambda \mathrm{x}+\left(\mathrm{k}_{3} \sinh \lambda \mathrm{x}+\mathrm{k}_{4} \cosh \lambda \mathrm{x}\right) \cos \lambda \mathrm{x}\right]---$ $--(40)$

The constants $\mathrm{k}_{1}, \mathrm{k}_{2}, \mathrm{k}_{3}$ and $\mathrm{k}_{4}$ are determined for different types of beams by applying the boundary conditions at the ends. The relative end settlement is used as a boundary condition at one ends.

1- Pin ended beam: the deflection $(\mathrm{w}=0)$ and the bending moment $(\mathrm{w}=0)$ at $(\mathrm{x}=0)$ and the deflection $(\mathrm{w}=\Delta)$ and the bending moment $(\mathrm{w}=0)$ at $(\mathrm{x}=\mathrm{L})$, apply these conditions on equation (39) and solve for the constants to obtain:

$\mathrm{k}_{1}=-\mathrm{Qo} / \mathrm{K}$

$(40-a)$ 
$\mathrm{k}_{2}=\left(\mathrm{k}_{3} \cot \lambda \mathrm{L}+\mathrm{Qo} / \mathrm{K}\right) \tanh \lambda \mathrm{L}$ (40-b)

$\Delta \operatorname{csch} \lambda \mathrm{L} \sec \lambda \mathrm{L}+\mathrm{Qo} / \mathrm{K}(\operatorname{coth} \lambda \mathrm{L}-\operatorname{csch} \lambda \mathrm{L} \sec \lambda \mathrm{L}-\tanh \lambda \mathrm{L})$

$\mathrm{k}_{3}=$

$(\operatorname{coth} \lambda \mathrm{L} \tan \lambda \mathrm{L}+\tanh \lambda \mathrm{L} \cot \lambda \mathrm{L})$

$\mathrm{k}_{4}=0$

$(40-d)$

when $(\Delta=0)$, i.e. no settlement, the resulting equation of the deflection is exactly the same as that given in ref.[2]:

$$
\cosh \lambda x \cos \lambda(x-L)+\cosh \lambda(x-L) \cos \lambda x
$$

$\mathrm{w}=\mathrm{Qo} / \mathrm{K}[1-$ $--(41)$

$$
(\cosh \lambda \mathrm{L}+\cos \lambda \mathrm{L})
$$

The bending moment equation becomes as:

$$
\sinh \lambda x \sin \lambda(x-L)+\sinh \lambda(x-L) \sin \lambda x
$$

$\mathrm{M}=-\mathrm{Qo} /\left(2 \lambda^{2}\right)[$

$$
(\cosh \lambda \mathrm{L}+\cos \lambda \mathrm{L})
$$

Using the (Rayleigh. Ritz) energy method for the functional given in equation (1) and employing the (n) terms approximate function $(\mathrm{w}=\Sigma \mathrm{An} \sin \mathrm{n} \pi \mathrm{x} / \mathrm{L})$. A straight forward extremization of the functional with respect to (An) leads to the following approximation:

$$
\mathrm{w}_{\infty}=\Sigma \text { - } 4 \mathrm{QoL}{ }^{4} /\left(\mathrm{n}^{5} \pi^{5} \mathrm{EI}\right)
$$

$$
\mathrm{n}=\mathbf{1} \quad\left[1+\mathrm{KL}{ }^{4} /\left(\mathrm{n}^{4} \pi^{4} \mathrm{EI}\right)-\mathrm{P} / \mathrm{Po}\right]
$$

where $\mathrm{n}=1,3,5$, etc. 
and the bending moment:

$$
\infty \quad 4 \mathrm{QoL}^{2} /\left(\mathrm{n}^{3} \pi^{3}\right)
$$

$\mathrm{M}=\Sigma$ $\sin (n \pi x / L)$

$-(44)$

$$
\mathbf{n}=\mathbf{1} \quad\left[1+\mathrm{KL}{ }^{4} /\left(\mathrm{n}^{4} \pi^{4} \mathrm{EI}\right)-\mathrm{P} / \mathrm{Po}\right]
$$

Including the relative end settlement into account, the approximate deflection equation becomes as below:

$\mathrm{w}=\Sigma \mathrm{An} \sin \mathrm{n} \pi \mathrm{x} / \mathrm{L}+\Delta \mathrm{x} / \mathrm{L}$

Following the same procedures of (Rayleigh-Ritz) method, the resulting equations of the deflection and the bending moment are:

$$
\infty \quad 2(2 \mathrm{Qo}-\mathrm{K} \Delta) \mathrm{L}^{4} /\left(\mathrm{n}^{5} \pi^{5} \mathrm{EI}\right)
$$

$\mathrm{W}=\Sigma$

$$
\sin (n \pi x / L)+\Delta x / L
$$

$$
\mathbf{n}=\mathbf{1} \quad\left[1+\mathrm{KL}^{4} /\left(\mathrm{n}^{4} \pi^{4} \mathrm{EI}\right)-\mathrm{P} / \mathrm{Po}\right]
$$

and

$$
\infty \quad 2(2 \mathrm{Qo}-\mathrm{K} \Delta) \mathrm{L}^{2} /\left(\mathrm{n}^{3} \pi^{3}\right)
$$

$\mathrm{M}=\Sigma$ $\sin (n \pi x / L)$

$$
\mathbf{n}=\mathbf{1} \quad\left[1+\mathrm{KL}^{4} /\left(\mathrm{n}^{4} \pi^{4} \mathrm{EI}\right)-\mathrm{P} / \mathrm{Po}\right]
$$

The exact solution of pin ended beam using the elementary mechanics of material method [4-8]:

$\mathrm{W}=\mathrm{QoL}^{4} /(24 \mathrm{EI})\left[(\mathrm{x} / \mathrm{L})^{4}-2(\mathrm{x} / \mathrm{L})^{2}+(\mathrm{x} / \mathrm{L})\right]+\Delta \mathrm{x} / \mathrm{L}$ $-(47)$

and

$\mathrm{M}=\mathrm{QoL}^{2} / 2\left[(\mathrm{x} / \mathrm{L})-(\mathrm{x} / \mathrm{L})^{2}\right]$

$--(48)$ 
The comparison of the results obtained from the exact solution and the (Rayleigh-Ritz) energy method is shown in Table (3) and Figs.(3 and 4). The results show that the energy method using one term series approximate solution $(n=1)$ gives close results to the exact solution and practically accepted, the accuracy of the solution increases when two or more terms are used $(n=3,5,7$ and 9), beyond this limit the accuracy of the solution does not change, thus 5 terms $(n=9)$ is quite enough to give results very close to the exact solution. Figs.(4-8) show the effect of the soil sub-grade reaction value $(\mathrm{K})$ and the relative settlement $(\mathrm{)}$ on the deflection and bending moment, as shown increasing of $(\mathrm{K})$ decreases the curvature of the beam, thus decreasing the deflection and bending moment. The effect of (K) is clearer in Fig.(9 and 10), the deflection and bending moment exponentially decreased as $(\mathrm{K})$ is increased. The same behavior is observed for beams with settlements $(12.5$ and $25 \mathrm{~mm}$ ). Fig.(10) shows that negative moments are observed at $(\mathrm{K} / \mathrm{Ec}=0.06 \%)$ for settlement $(12.5 \mathrm{~mm})$ and $(\mathrm{K} / \mathrm{Ec}=0.03 \%)$ for settlement $(25 \mathrm{~mm})$, for this reason the concrete tie beams resting on elastic foundation is reinforced at the top and bottom to resist the positive and negative moments.

2- Fixed ended beam: the deflection $(\mathrm{w}=0)$ and the slope $\left(\mathrm{w}^{\prime}=0\right)$ at $(\mathrm{x}=0)$ and the deflection $(\mathrm{w}=\Delta)$ and the slope $\left(\mathrm{w}^{\prime}=0\right)$ at $(\mathrm{x}=\mathrm{L})$, apply these conditions to equation (39) and solve for the constants to obtain:

$\mathrm{k}_{1}=-\mathrm{Qo} / \mathrm{K}$

(49-a)

$\mathrm{k}_{2}=\mathrm{k}_{4} / 2(\operatorname{coth} \lambda \mathrm{L}+\cot \lambda \mathrm{L})+\mathrm{Qo} / \mathrm{K}(\operatorname{coth} \lambda \mathrm{L}-\cot \lambda \mathrm{L})$

(49-b)

$\mathrm{k}_{3}=-\mathrm{k}_{2}$

$(49-c)$

$2[\mathrm{Qo} / \mathrm{K}(\cosh \lambda \mathrm{L} \cos \lambda \mathrm{L}-1)+\Delta] \sinh \lambda \mathrm{L} \sin \lambda \mathrm{L}+\mathrm{Qo} / \mathrm{K}(\sinh \lambda \mathrm{L} \cos \lambda \mathrm{L}-\cos \lambda \mathrm{L}$ $\sin \lambda \mathrm{L})^{2}$

$\mathrm{k}_{4}=$

$---(49-d)$

$2(\sinh \lambda \mathrm{L} \sin \lambda \mathrm{L})^{2}+(\sinh \lambda \mathrm{L} \cos \lambda \mathrm{L})^{2}-(\cosh \lambda \mathrm{L} \sin \lambda \mathrm{L})^{2}$ 
Using the (Rayleigh-Ritz) energy method for the functional given in equation (1) and employing the (n) terms approximate function which satisfy the boundary conditions of the fixed ended beam:

$\mathrm{w}=\sum \mathrm{An}[1-\cos (2 \mathrm{n} \pi \mathrm{x} / \mathrm{L})]+\Delta\left[3(\mathrm{x} / \mathrm{L})^{2}-2(\mathrm{x} / \mathrm{L})^{3}\right]$

$-(50)$

following the same procedures used in pin ended beam, the resulting equation of the deflection and the bending moment are shown below:

$\infty \quad(2 \mathrm{Qo}-\mathrm{K} \Delta) \mathrm{L}^{4} /\left(16 \mathrm{n}^{4} \pi^{4} \mathrm{EI}\right)$ 


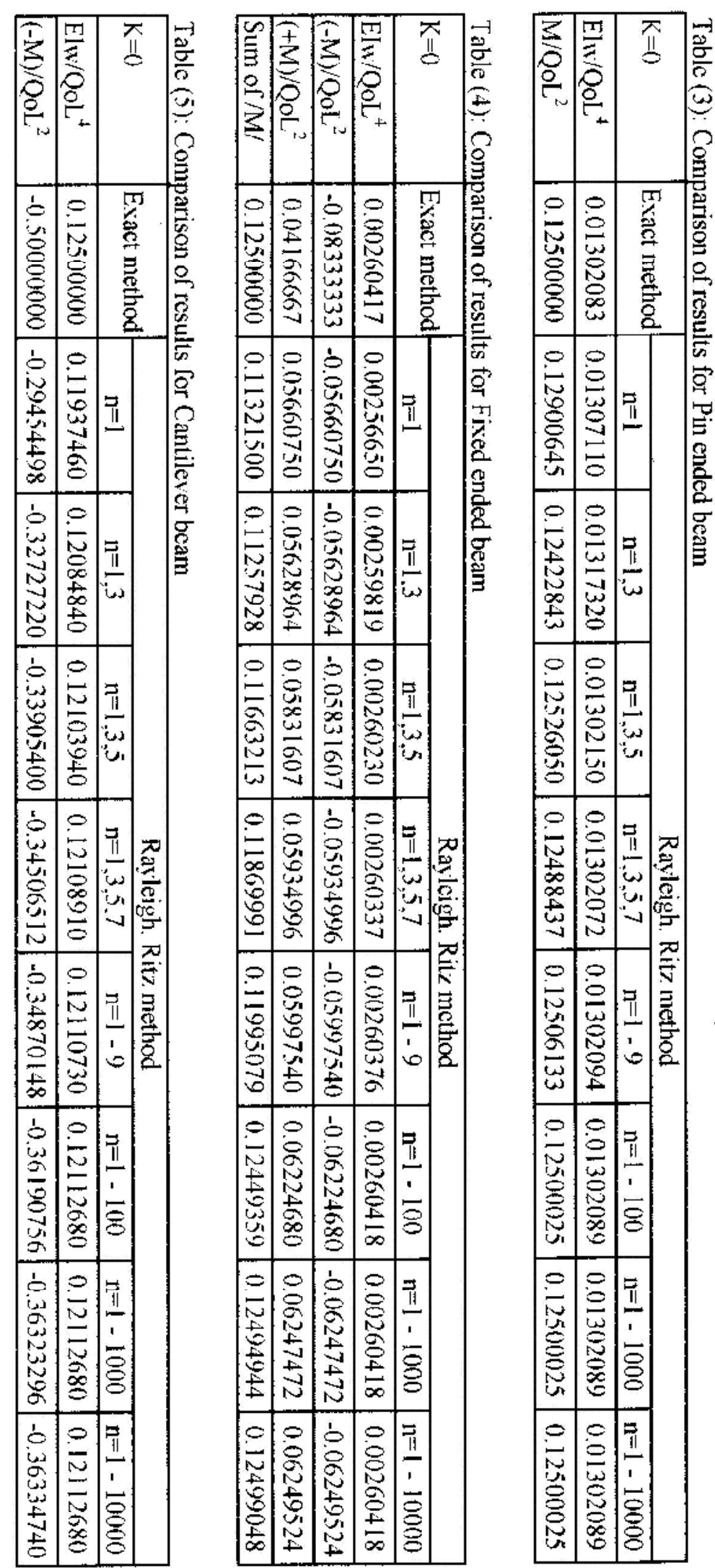


$\begin{array}{llll}\text { Al-Rafidain Engineering } & \text { Vol.16 } & \text { No.3 } & \text { Aug. } 2008\end{array}$

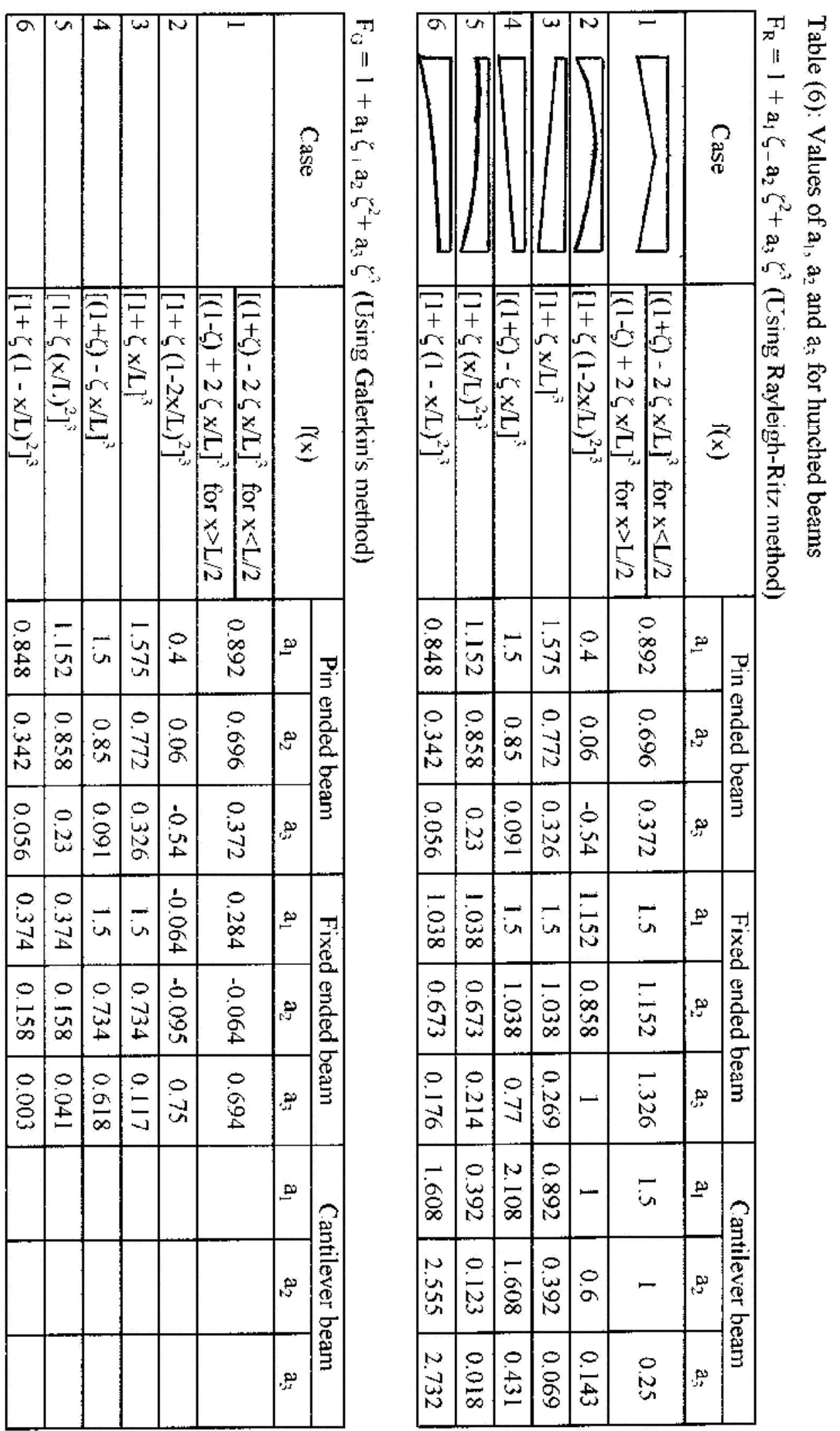




\begin{tabular}{llll} 
Al-Rafidain Engineering & Vol.16 & No.3 & Aug. 2008 \\
\hline
\end{tabular}
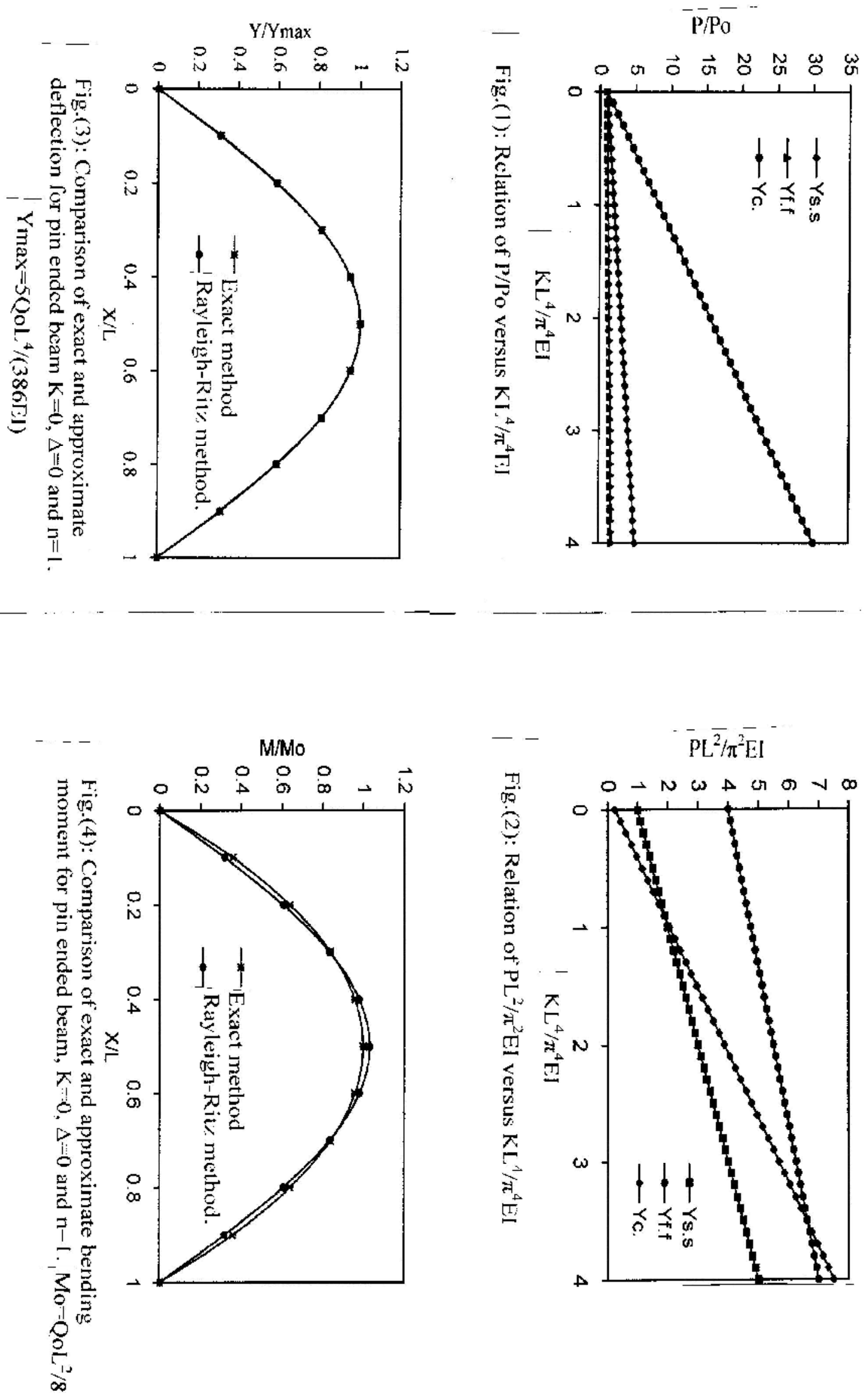

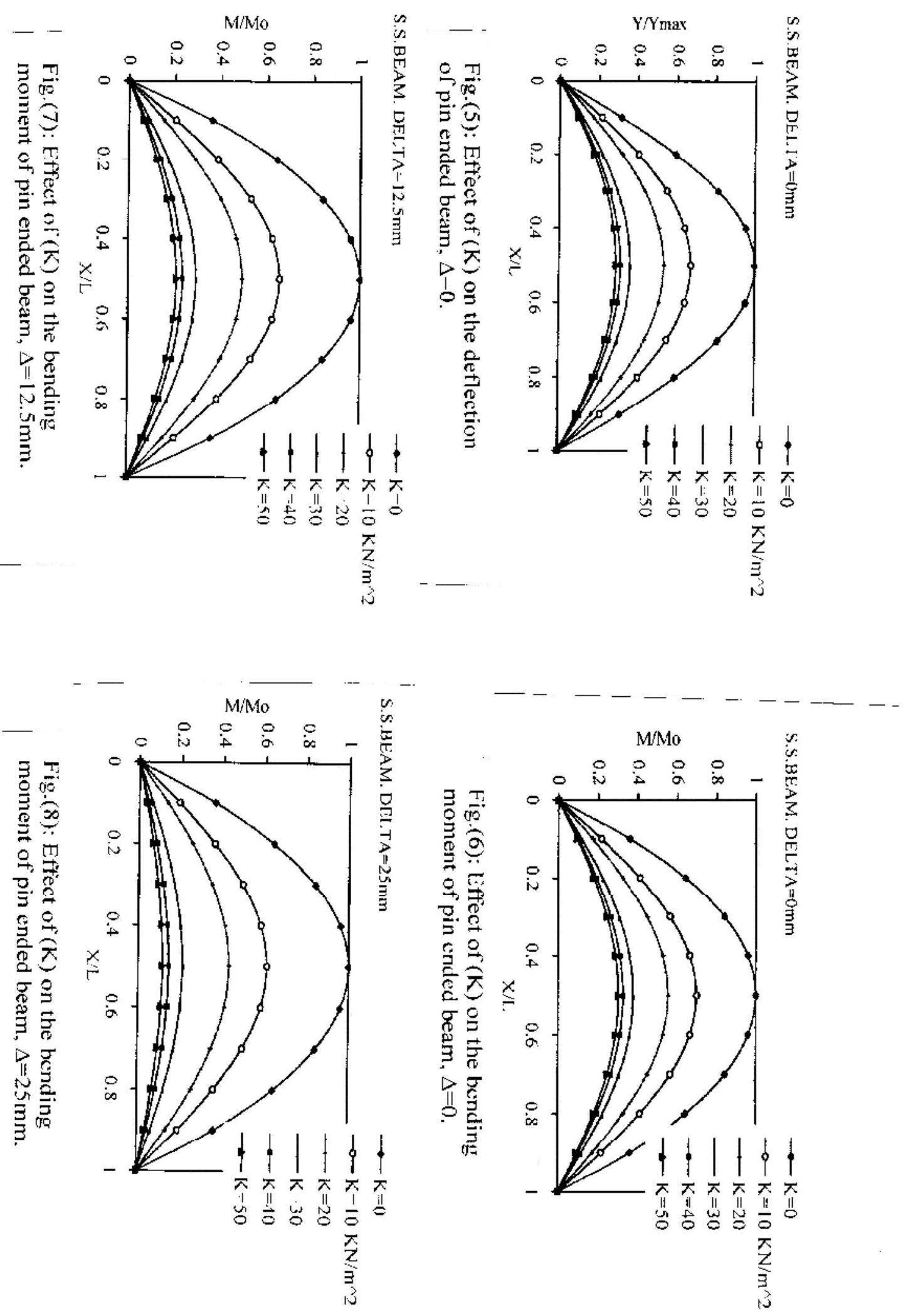


$\begin{array}{llll}\text { Al-Rafidain Engineering } & \text { Vol.16 } & \text { No.3 } & \text { Aug. } 2008\end{array}$
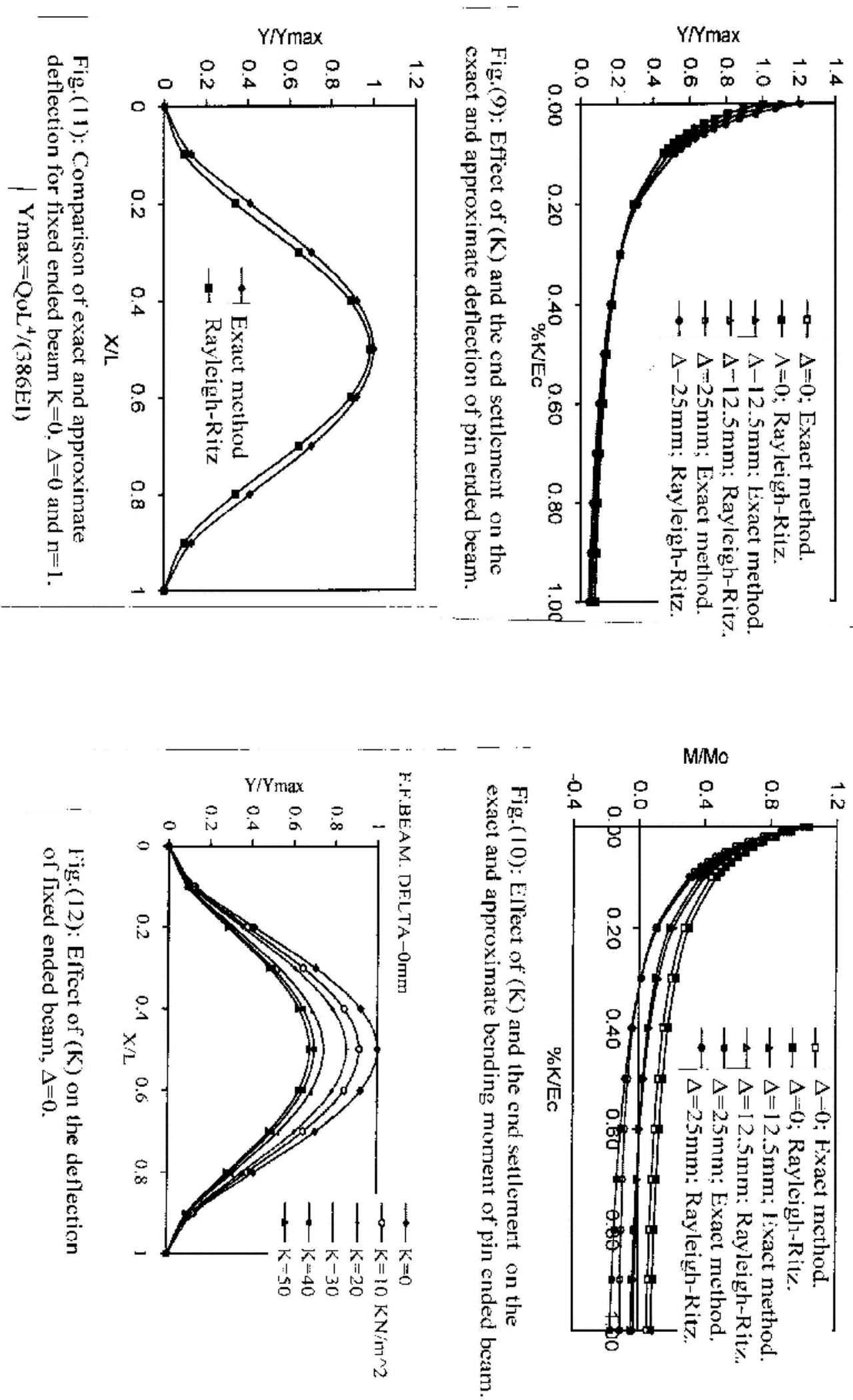
$\mathrm{W}=\Sigma$ $[1-\cos (2 \mathrm{n} \pi \mathrm{x} / \mathrm{L})]+\Delta\left[3(\mathrm{x} / \mathrm{L})^{2}-2(\mathrm{x} / \mathrm{L})^{3}\right]-$

$$
\mathbf{n}=\mathbf{1} \quad\left[1+3 \mathrm{KL}^{4} /\left(16 \mathrm{n}^{4} \pi^{4} \mathrm{EI}\right)-\mathrm{P} / \mathrm{Po}\right]
$$

and

$$
\infty \quad-(2 \mathrm{Qo}-\mathrm{K} \Delta) \mathrm{L}^{2} /\left(4 \mathrm{n}^{2} \pi^{2}\right)
$$

$\mathrm{M}=\Sigma$ $\cos (2 n \pi x / L)+6 E I \Delta / L^{2}(2 x / L-1)$ $-(52)$

$$
\mathbf{n = 1} \quad\left[1+3 \mathrm{KL}^{4} /\left(16 \mathrm{n}^{4} \pi^{4} \mathrm{EI}\right)-\mathrm{P} / \mathrm{Po}\right]
$$

The exact solution according to elementary mechanics of material method [4-8]:

$\mathrm{w}=\mathrm{QoL}^{4} /(24 \mathrm{EI})\left[(\mathrm{x} / \mathrm{L})^{4}-2(\mathrm{x} / \mathrm{L})^{3}+(\mathrm{x} / \mathrm{L})^{2}\right]+\Delta\left[3(\mathrm{x} / \mathrm{L})^{2}-2(\mathrm{x} / \mathrm{L})^{3}\right]$

and

$\mathrm{M}=\mathrm{QoL}^{2} / 12\left[6(\mathrm{x} / \mathrm{L})-6(\mathrm{x} / \mathrm{L})^{2}-1\right]+6 \mathrm{EI} \Delta / \mathrm{L}^{2}(2 \mathrm{x} / \mathrm{L}-1)$ $--(54)$

Table (4) and Fig.(11) show that the (Rayleigh-Ritz) method gives close results to the exact method, the accuracy of the solution increased with number of terms up to 5 terms, beyond this limit the accuracy of the solution does not change. Rayleigh-Ritz method gives negative moment about $(60-75 \%)$ of that obtained by exact method while the positive moment is greater by about $(21-50 \%)$.

Figs.(12-17) show the effect of (K) on the deflection and bending moment. The bending moment increased in one end and decreased in the other end due to the end settlement, because the bending moment developed due to the settlement $\left(6 \mathrm{EI} / \mathrm{L}^{2}\right)$ is added algebraically to that developed due to the lateral load.

3- Cantilever beam: the deflection $(\mathrm{w}=0)$ and the slope $(\mathrm{w}=0)$ at $(\mathrm{x}=0)$ and the bending moment $\left(w^{\prime \prime}=0\right)$ and the shear force $\left(\mathrm{w}^{\prime \prime}+\mathrm{k}_{1}{ }^{2} \mathrm{w}^{\prime}=0\right)$ at $(\mathrm{x}=\mathrm{L})$, apply these conditions to equation (39) and solve for the constants to obtain: 
$\mathrm{k}_{1}=-\mathrm{Qo} / \mathrm{K}$

(55-a)

$\mathrm{k}_{2}=-\mathrm{k}_{3}$

$\mathrm{k}_{3}=\left(\mathrm{k}_{1}+\mathrm{k}_{4}\right) / 2 \tan \lambda \mathrm{L}+\left(\mathrm{k}_{1}-\mathrm{k}_{4}\right) / 2 \tanh \lambda \mathrm{L}$ $(55-\mathrm{c})$

$$
(\cosh \lambda \mathrm{L} \sin \lambda \mathrm{L})^{2}+(\sinh \lambda \mathrm{L} \cos \lambda \mathrm{L})^{2}
$$

$\mathrm{k}_{4}=\mathrm{Qo} / \mathrm{K}$

$(55-d)$

$$
2(\cosh \lambda L \cos \lambda L)^{2}+(\cosh \lambda L \sin \lambda L)^{2}-(\sinh \lambda L \cos \lambda L)^{2}
$$

Using the (Rayleigh-Ritz) energy method for the functional given in equation (1) and employing the (n) terms approximate function which satisfy the boundary conditions of the fixed ended beam:

$\mathrm{w}=\sum \mathrm{An}[1-\cos (\mathrm{n} \pi \mathrm{x} / 2 \mathrm{~L})]$

Following the same procedures used in pin ended beam, the resulting equation of the deflection and the bending moment are shown below:

$$
\infty \quad \beta_{1} \mathrm{QoL}^{4} /\left(\mathrm{n}^{4} \pi^{4} \mathrm{EI}\right)
$$

$\mathrm{W}=\Sigma$

$$
[1-\cos (n \pi x / 2 L)]
$$

$$
\mathbf{n}=\mathbf{1} \quad\left[1+\beta_{2} \mathrm{KL}^{4} /\left(\mathrm{n}^{4} \pi^{4} \mathrm{EI}\right)-\mathrm{P} / \mathrm{Po}\right]
$$

and

$$
\infty \quad-\beta_{1} \mathrm{QoL}^{2} /\left(4 \mathrm{n}^{2} \pi^{2}\right)
$$

$\mathrm{M}=\Sigma$ $\cos (\mathrm{n} \pi \mathrm{x} / 2 \mathrm{~L})$

$-(58)$

$$
\mathbf{n}=\mathbf{1} \quad\left[1+\beta_{2} \mathrm{KL}^{4} /\left(\mathrm{n}^{4} \pi^{4} \mathrm{EI}\right)-\mathrm{P} / \mathrm{Po}\right]
$$

where $\beta_{1}=32(\pi-2) / \pi$ and $\beta_{2}=16(3 \pi-8) / \pi$ 
The exact solution according to elementary strength of material method [4-8]:

$\mathrm{w}=\mathrm{QoL}^{4} /(24 \mathrm{EI})\left[(\mathrm{x} / \mathrm{L})^{4}-4(\mathrm{x} / \mathrm{L})^{3}+6(\mathrm{x} / \mathrm{L})^{2}\right]$

$-(59)$

and

$\mathrm{M}=\mathrm{QoL}^{2} / 2\left[2(\mathrm{x} / \mathrm{L})-(\mathrm{x} / \mathrm{L})^{2}-1\right]$

$--(60)$ 


$\begin{array}{llll}\text { Al-Rafidain Engineering } & \text { Vol.16 } & \text { No.3 } & \text { Aug. } 2008\end{array}$
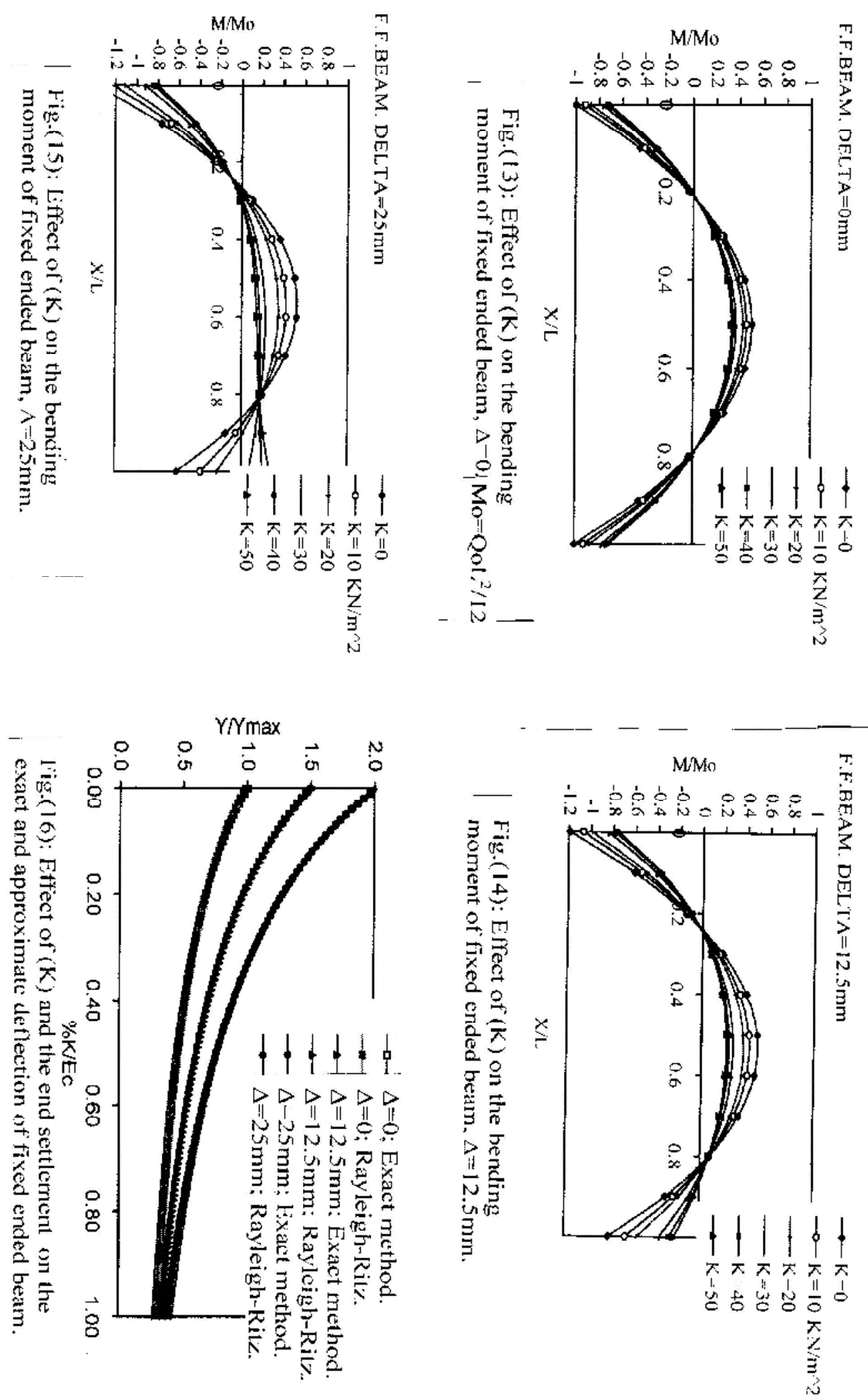


$\begin{array}{llll}\text { Al-Rafidain Engineering } & \text { Vol.16 } & \text { No.3 } & \text { Aug. } 2008\end{array}$
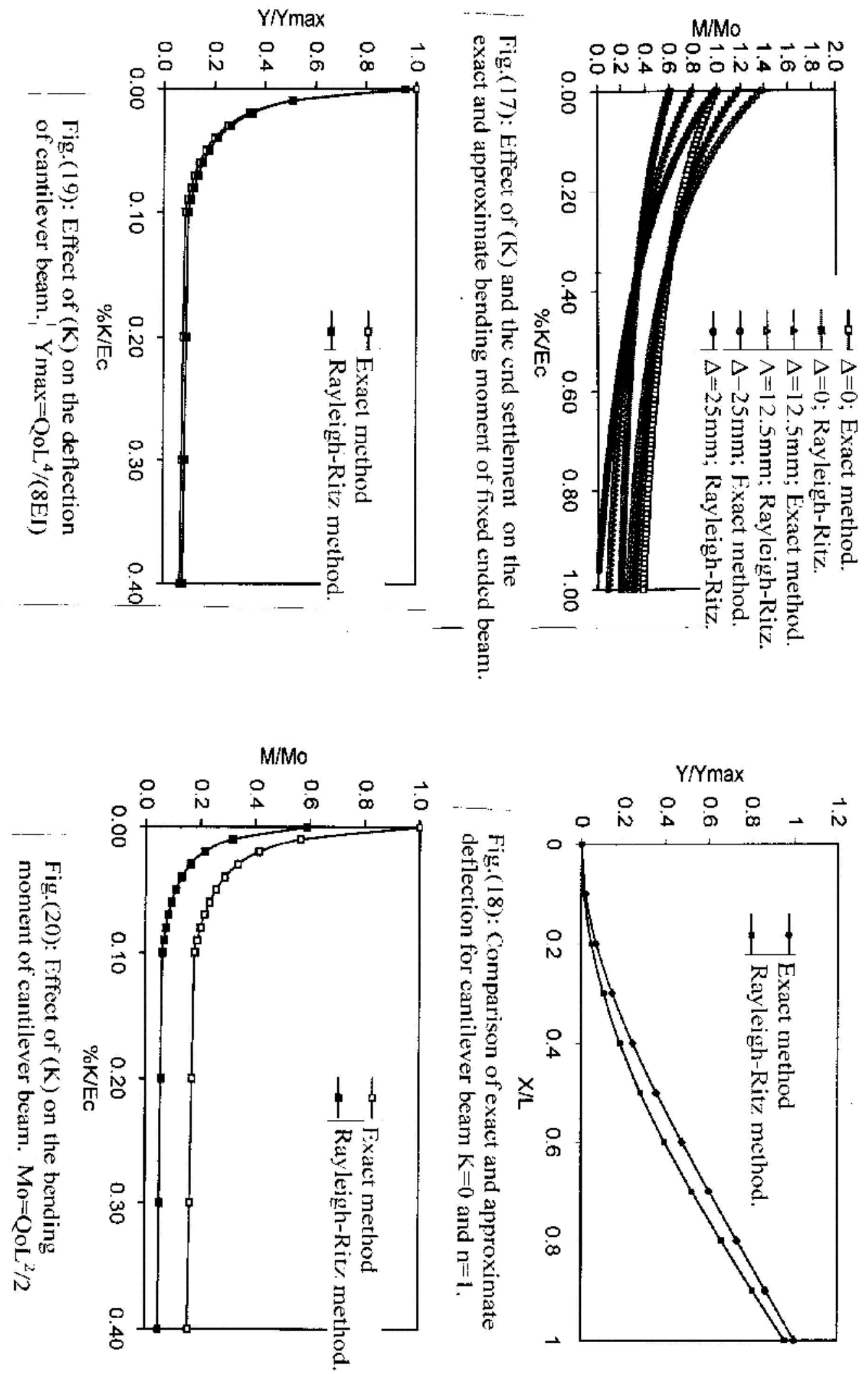
The same conclusion and behavior are obtained as shown in Table (5) and Figs.(18-20). the bending moment obtained by (Rayleigh-Ritz) method is about $(59-75 \%)$ of that obtained by the exact method. The existence of sub-grade soil supporting the cantilever beam has greater effect than pin ended and fixed ended beams, the reduction of the deflection and the bending moment to be less than $(10 \%)$.

\section{IV- Elastic buckling of non-prismatic beams on elastic foundation:}

Rayleigh-Ritz and Galerkin's methods are used to derive the general deflection equation and bending moment including the effect of lateral load $\mathrm{Q}(\mathrm{x})$, axial load $(\mathrm{P})$, soil sub-grade reaction and variation of the cross section. Six types of linear and parabolic changing cross section are considered.

Galerkin's method is another method for finding approximate solution to a differential equation. This method involves direct use of the differential equations. It does not require the existence of a functional, for this reason the method is used when the functional of the problem is not available, difficult or complicated.

For the differential equation $(\mathrm{Du}=\mathrm{f})$, where $\mathrm{D}$ is the differential operator and $\mathrm{u}$ is the solution. If the approximate solution $\left(\mathrm{u}=\sum \mathrm{a}_{\mathrm{i}} \quad \mathrm{i}\right)$, where $\left({ }_{i}\right)$ are shape functions and $\left(a_{i}\right)$ are constants. The integral of the out of balance of the differential equation can be written as below:

$$
(\mathrm{Du}-\mathrm{f}) \quad{ }_{\mathrm{i}} \mathrm{dV}=0
$$

Both methods (Rayleigh-Ritz and Galerkin's) are applied to the three types of beams (pin ended, fixed ended and cantilever) using the same deflection functions that used for prismatic beams in previous sections.

\section{1- Pin ended beam:}

$$
4 \mathrm{QoL}^{4} /\left(\mathrm{n}^{5} \pi^{5} \mathrm{EI}\right)
$$


$\mathrm{W}=\Sigma$ $\sin (n \pi x / L)$

$$
\mathrm{n}=\mathbf{1} \quad\left[\mathrm{F}+\mathrm{KL}^{4} /\left(\mathrm{n}^{4} \pi^{4} \mathrm{EI}\right)-\mathrm{P} / \mathrm{Po}\right]
$$

and

$$
\infty \quad 4 \mathrm{QoL}^{2} /\left(\mathrm{n}^{3} \pi^{3}\right) \mathrm{f}(\mathrm{x})
$$

$$
\mathrm{n}=\mathbf{1} \quad\left[\mathrm{F}+\mathrm{KL}^{4} /\left(\mathrm{n}^{4} \pi^{4} \mathrm{EI}\right)-\mathrm{P} / \mathrm{Po}\right]
$$

where:

$\mathrm{F}=1+\mathrm{a}_{1} \zeta+\mathrm{a}_{2} \zeta^{2}+\mathrm{a}_{3} \zeta^{3}$

$\zeta=\mathrm{h}_{2} / \mathrm{h}_{1}-1$

$\mathrm{h}_{1}$ and $\mathrm{h}_{2}$ are the smallest and largest depth of the hunched beam respectively.

$f(x)$ is the function of changing the moment of inertia shown in Table (6). $a_{1}, a_{2}, a_{3}$ are constants depend on the shape of the non-prismatic beam. The values of these constants are determined using Rayleigh-Ritz and Galerkin's methods and shown in Table (6). Equations (62 and 63) are similar to those derived for prismatic beams, only one additional factor (F), when $\left(\mathrm{h}_{1}=\mathrm{h}_{2}, \zeta=0\right.$ and $\left.\mathrm{F}=1\right)$ the resulting form of equations (62 and $63)$ become similar to equations (43 and 44 ).

\section{2- Fixed ended beam:}

$$
\infty \quad \mathrm{QoL}^{4} /\left(8 \mathrm{n}^{4} \pi^{4} \mathrm{EI}\right)
$$

$$
\mathrm{W}=\Sigma
$$

$$
\mathrm{n}=\mathbf{1} \quad\left[\mathrm{F}+3 \mathrm{KL}^{4} /\left(16 \mathrm{n}^{4} \pi^{4} \mathrm{EI}\right)-\mathrm{P} / \mathrm{Po}\right]
$$

and 


$$
\begin{aligned}
& \infty \quad-\mathrm{QoL}^{2} /\left(2 n^{2} \pi^{2}\right) \mathrm{f}(\mathrm{x}) \\
& \mathrm{M}=\Sigma \\
& -(65) \\
& \mathbf{n}=\mathbf{1} \quad\left[\mathrm{F}+3 \mathrm{KL}^{4} /\left(16 \mathrm{n}^{4} \pi^{4} \mathrm{EI}\right)-\mathrm{P} / \mathrm{Po}\right]
\end{aligned}
$$

Equations (64 and 65) are same as equations (51 and 52) when $(\Delta=0)$.

\section{3- Cantilever beam:}

$$
\begin{aligned}
& \beta_{1} \mathrm{QoL}^{4} /\left(\mathrm{n}^{4} \pi^{4} \mathrm{EI}\right)
\end{aligned}
$$

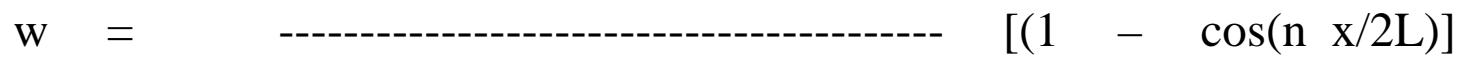

$$
\begin{aligned}
& \text { (66) } \\
& \mathrm{n}=1 \quad\left[\mathrm{~F}+\beta_{2} \mathrm{KL}{ }^{4} /\left(\mathrm{n}^{4} \pi^{4} \mathrm{EI}\right)-\mathrm{P} / \mathrm{Po}\right]
\end{aligned}
$$

And

$$
\infty \quad-\beta_{1} \operatorname{QoL}^{2} /\left(4 n^{2} \pi^{2}\right) f(x)
$$

$\mathrm{M}=\Sigma$ $\cos (\mathrm{n} \pi \mathrm{x} / 2 \mathrm{~L})$ $(67)$

$$
\mathbf{n}=\mathbf{1} \quad\left[\mathrm{F}+\beta_{2} \mathrm{KL}^{4} /\left(\mathrm{n}^{4} \pi^{4} \mathrm{EI}\right)-\mathrm{P} / \mathrm{Po}\right]
$$

Equations (66 and 67) are similar to equations (57 and 58) when $(\Delta=0)$.

\section{Conclusions:}

1- The critical load (Pcr) of the beam on elastic foundation is twice the critical load for beam when $(\mathrm{K}=0)$ for the same properties for the case $(\alpha / 2)^{2}=\beta$.

2- The buckling load (Pcr) for fixed ended beam is greater than pin ended beam by $(\sqrt{3})$ with the same properties and for the case $(\alpha / 2)^{2}=\beta$.

3- The buckling load (Pcr) for cantilever beam is about (2/3) of the pin ended beam with the same properties and for the case $(\alpha / 2)^{2}=$ $\beta$. 
4- The (Rayleigh-Ritz) method using one term series approximate solution $(n=1)$ gives close results to the exact method, the accuracy of the solution increased when two or more terms are used up to five terms, beyond this limit the accuracy of the solution does not changed.

5- The increasing of soil sub-grade reaction $(\mathrm{K})$ decreases the curvature of the beam, thus decreasing of the deflection and the bending moment exponentially as $(\mathrm{K})$ is increased.

6- In fixed ended beams, Rayleigh-Ritz method gives negative moment about $(60-75 \%)$ of that obtained by exact method while the positive moment is greater by about $(21-50 \%)$.

7- In cantilever beams, the bending moment obtained by (RayleighRitz) method is about $(59-75 \%)$ of that obtained by the exact method. The existence $(\mathrm{K})$ reduces the deflection and the bending moment to less than (10\%).

8- The general equation obtained for prismatic and non-prismatic beams are exactly similar for all types (pin ended, fixed ended and cantilever). The factor $(\mathrm{F})$ is to be added to the equations which represent the effect of the variation of the cross section. This factor is unity in prismatic beams.

\section{References:}

1- Timoshenko, S.P. and Gere, J.M., "Theory of Elastic Stability", Second edition, McGraw-Hill International Book Company, 1985.

2- Dym, C.L. and Shames, I. H., "Solid Mechanics A Variational Approach", McGraw-Hill Kogakusha, Ltd., Tokyo, Japan,1970.

3- Washezu, K., "Variational Methods in Elasticity and Plasticity", $2^{\text {nd }}$ edition, Pergamon Press, Oxford, England, 1975.

4- Gere, J. M. and Timoshenko, S.P., "Mechanics of Materials", $2^{\text {nd }}$ edition, CBS Publishers and Distributors, New Delhi, India, 2004.

5- Gere, J. M., "'Mechanics of Materials", Brooks/Cole, $5^{\text {th }}$ edition, USA, 2001.

6- Morrow, H.W., "Statics and Strength of Materials", $3^{\text {rd }}$ edition, Prentice Hall, New Jersi, USA, 1998.

7- Spiegel, L. and Limbrunner, G.F., "Applied Statics and Strength of Materials", $4^{\text {th }}$ edition, Pearson Prentice Hall, New Jersi, USA, 2004.

8- Raymond, P., "Solid Mechanics in Engineering", John Wiley and Sons, Ltd., England, 2001. 
